\title{
A biodegradable and biobased intumescent flame- retardant for polylactic acid textiles and composites
}

Citation for published version (APA):

Maqsood, M. (2020). A biodegradable and biobased intumescent flame-retardant for polylactic acid textiles and composites. [Doctoral Thesis, Maastricht University]. Maastricht University. https://doi.org/10.26481/dis.20200610mm

Document status and date:

Published: 01/01/2020

DOI:

10.26481/dis.20200610mm

Document Version:

Publisher's PDF, also known as Version of record

\section{Please check the document version of this publication:}

- A submitted manuscript is the version of the article upon submission and before peer-review. There can be important differences between the submitted version and the official published version of record.

People interested in the research are advised to contact the author for the final version of the publication, or visit the DOI to the publisher's website.

- The final author version and the galley proof are versions of the publication after peer review.

- The final published version features the final layout of the paper including the volume, issue and page numbers.

Link to publication

\footnotetext{
General rights rights.

- You may freely distribute the URL identifying the publication in the public portal. please follow below link for the End User Agreement:

www.umlib.nl/taverne-license

Take down policy

If you believe that this document breaches copyright please contact us at:

repository@maastrichtuniversity.nl

providing details and we will investigate your claim.
}

Copyright and moral rights for the publications made accessible in the public portal are retained by the authors and/or other copyright owners and it is a condition of accessing publications that users recognise and abide by the legal requirements associated with these

- Users may download and print one copy of any publication from the public portal for the purpose of private study or research.

- You may not further distribute the material or use it for any profit-making activity or commercial gain

If the publication is distributed under the terms of Article $25 \mathrm{fa}$ of the Dutch Copyright Act, indicated by the "Taverne" license above, 


\section{Propositions}

Belonging to the dissertation:

\section{A Biodegradable and Biobased Intumescent Flame-retardant for Polylactic Acid Textiles and Composites}

1. Flame retardancy is an active research subject, developing numerous and efficient strategies to endow polymers with good fire-resistant properties.

2. Bioplastics issued from renewable resources represent an interesting alternative to polymers made of fossil carbon, which could be helpful in reducing carbon footprint.

3. From variety of biomolecules and green processes, new flame-retardant solutions can be proposed.

4. Most of the conventional flame-retardants are non-biodegradable and if disposed in the landfill, microorganisms in the soil or water cannot degrade them. Hence, they remain in the environment for long time and may find their way in the food chain.

5. In bicomponent fibers, selection of appropriate polymer for each component (preferably matrix and reinforcement from same polymer) is necessary for a stable and uniform interface for better adhesion of the components.

6. The optimization of the additives composition, temperature profiles and thermal processing conditions are the key factors to obtain the desired functional and mechanical properties of the fibers containing flame-retardant bio-macromolecules.

7. Some of the bio-macromolecules can be obtained as a waste material or a by-product from wood industry or from agro or food industry therefore, can present another added value to these industries.

8. The repossessions and succeeding applications of bio-macromolecules as flame-retardants may fulfill the current requirements of valorization of wood, food and agro-industries thus, avoiding their landfill detention.

9. Textile is one of the world's largest market mainly based on synthetic fibres used in consumer products and are subjected to flame-retardant requirements, which need to be taken into account during product development. 